\title{
A tradução intersemiótica de Jakobson revisitada e uma pequena análise dos quadrinhos de Asterix
}

\author{
Adriano Clayton da Silva \\ Universidade Estadual de Campinas (UNICAMP), Campinas, São Paulo, Brasil \\ drianovsk@bol.com.br \\ https://orcid.org/0000-0002-6556-884X
}

DOI: http://dx.doi.org/10.21165/el.v47i2.1953

\begin{abstract}
Resumo
Este trabalho busca repensar o conceito de tradução intersemiótica (TI) cunhado por Roman Jakobson, já que o próprio autor russo não o teria desenvolvido. Primeiramente, a TI é relacionada a duas ideias importantes do linguista: o esquema comunicativo e o processamento da linguagem através de metáforas e metonímias. A seguir, é feita uma releitura das ideias de signo e texto na TI de Jakobson, através do pensamento Peirceano e da Multimodalidade. Por fim, as ideias desenvolvidas são usadas nas análises de dois pares de vinhetas (fonte e alvo) de histórias em quadrinhos do personagem francês Asterix traduzidas para o público brasileiro. Como resultado, demonstra-se que a TI de Jakobson pode ser aplicada tanto na tradução de uma obra completa para outra (um livro em filme) quanto na tradução de unidades dentro dos quadrinhos (imagens em palavras) e também que a TI pode acontecer simultaneamente às traduções intra e interlingual, também cunhadas por Jakobson.
\end{abstract}

Palavras-chave: Roman Jakobson; tradução intersemiótica; história em quadrinhos; Asterix.

Jakobson's intersemiotic translation revisited and a small analysis of Asterix comics

\begin{abstract}
This paper seeks to rethink the intersemiotic translation (IT) concept, created by Roman Jakobson, since the Russian author himself wouldn't have developed it. Firstly, the IT is linked to two crucial ideas of the linguist: the communicative scheme and the language processing via metonymies and metaphors. Secondly, sign and text ideas in Jakobson's IT are reviewed via Peircean thought and Multimodality. Then the developed ideas are used in the analysis of two pairs of frames (source and target) from comic books of the French character Asterix. As result, it is demonstrated that Jakobson's IT can be applied both in the translation of a complete work into other (a book into a film) and in the translation of unities inside the comics (images into words). Also, it is showed that IT can occur simultaneously with intra and interlingual translations, concepts also created by Jakobson.
\end{abstract}

Keywords: Roman Jakobson; intersemiotic translation; comic book; Asterix.

\section{A teoria de Roman Jakobson}

Roman Jakobson foi um dos grandes teóricos da Linguística do século passado. Suas contribuições vão desde a inauguração e participação no círculo dos formalistas russos no começo do século XX, que veio a contribuir consideravelmente para a criação de uma teoria própria da linguagem poética e literária, passando pela reformulação das bases da Fonética e da Fonologia, até a apresentação de sua Teoria da Comunicação, juntamente com a ideia das funções da linguagem, no fim da década de 1960. 
Continuamente interessado no que acontecia não apenas no universo da linguagem, mas em diversas outras ciências da época (HOLENSTEIN, 1975), o autor russo frequentemente trazia inovações em seus textos e conferências, inovações estas que inevitavelmente afetavam e influenciavam as pessoas e campos de estudos que tinham acesso a tais materiais.

Entre suas formulações teóricas, Jakobson pensou a tradução pelo viés da Linguística. Através de seu texto bem conhecido, "Aspectos Linguísticos da Tradução" (JAKOBSON, 2003), originalmente publicado em 1959, ele buscou apresentar os mecanismos pelos quais a tradução funcionaria. Jakobson classificou as traduções em três tipos possíveis: intralingual, interlingual e intersemiótica. Como ele mesmo explicou:

1) A tradução intralingual, "ou reformulação (rewording) consiste na interpretação dos signos verbais por meio de outros signos da mesma língua." (Ibidem, p. 64). Esse tipo de tradução engloba dicionários, reformulações, paráfrases, etc.;

2) A tradução interlingual “ou tradução propriamente dita consiste na interpretação dos signos verbais por meio de alguma outra língua." (Ibidem, p. 65). Nesta categoria está o tipo de tradução mais conhecido pelo senso comum (entre línguas), mas também aí podem ser incluídos os dicionários bilíngues, trilíngues etc.;

3) A tradução intersemiótica (TI) "ou transmutação consiste na interpretação dos signos verbais por meio de sistemas de signos não-verbais.” (Ibidem, p. 65). Nesta categoria enquadra-se todo tipo de tradução de uma obra (um livro, um filme, um jogo de videogame) para outra forma de textualidade ou plataforma midiática, que pode ser um filme traduzido em livro, um livro traduzido em história em quadrinhos, um videogame traduzido em série de TV, entre diversas outras possibilidades e seus respectivos "vice-versas".

Quando o autor pensou os tipos de tradução acima, ele provavelmente o fez relacionando-os ao seu esquema de comunicação, que ele vinha desenvolvendo pela mesma época e que foi formalmente apresentado um ano depois no texto Linguistics and Poetics (JAKOBSON, 1960). Esse esquema diz que um emissor envia uma mensagem para um receptor, dentro de um contexto através de um contato (ou canal) e utilizando um código (Figura 1). Mas cada elemento desse esquema envolve um tipo de função da linguagem, respectivamente: emotiva, poética, conativa, referencial, fática e metalinguística. ${ }^{1}$

1 Devemos lembrar que Jakobson pensou esse esquema inicialmente para a língua falada, mas rapidamente o esquema passou a ser usado para vários casos de comunicação escrita. 
Figura 1. O modelo comunicativo de Jakobson

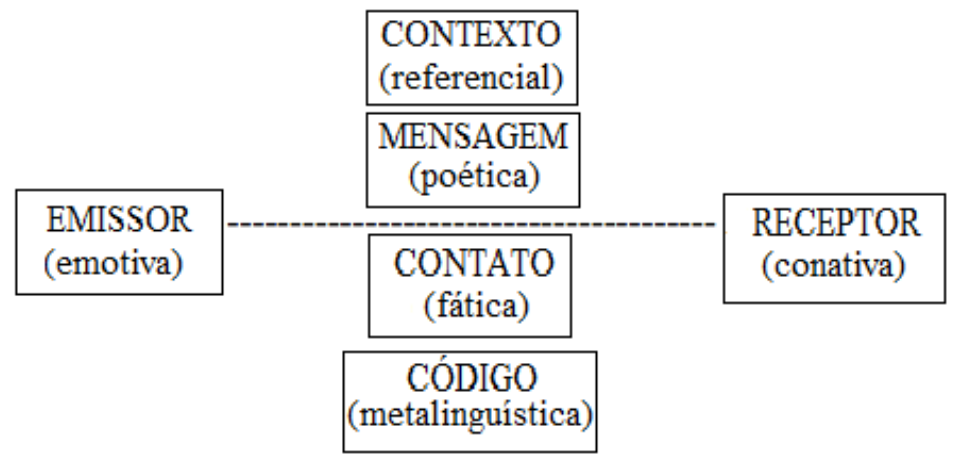

Fonte: Jakobson (1960)

Todas as funções estão presentes em qualquer tipo de ato comunicativo e não há, segundo Jakobson, qualquer ato composto de apenas um tipo de função. O que acontece é que elas sempre aparecem seguindo uma hierarquia, em que uma sobressai entre as outras, e é isso que causa as diferenciações entre os diversos atos comunicativos. De acordo com o autor (Ibidem, p. 34), cada função se destaca da seguinte forma:

1) Emotiva: a comunicação enfatiza sentimentos e emoções do emissor, podendo haver uso de interjeições e outros sinais que indiquem alguma emoção;

2) Poética: centrada na mensagem em si, é comum em textos poéticos e até publicitários, onde se busca chamar a atenção para a estrutura, o ritmo, a sonoridade da mensagem;

3) Conativa: geralmente enfatizada quando se deseja atingir o receptor ou mesmo obrigá-lo a algo, como as ordens e outras expressões imperativas, aí inclusas algumas formas de propaganda;

4) Referencial: A ênfase é sobre o assunto, privilegiando a objetividade. Muito comum em textos científicos e jornalísticos;

5) Fática: aparece quando se busca estabelecer, prolongar ou interromper a comunicação, como os cumprimentos e as despedidas;

6) Metalinguística: o próprio código é enfatizado, através de explicações e/ou descrições. Os dicionários e gramáticas são ótimos exemplos.

Retomando a classificação das traduções de Jakobson, temos que a tradução intralingual obrigaria à modificação da mensagem, mas os demais elementos permaneceriam os mesmos. Ao nível das funções, a referencial e a poética certamente se modificariam, com mais destaque para a referencial, mas as demais funções também poderiam ser modificadas. Um exemplo que o próprio autor russo traz é a possibilidade de dizer que alguém não é casado ao invés de dizer que ele é solteiro, dependendo do receptor (um pretendente ou um parente) e do contexto (uma confraternização ou um evento familiar). Se pensarmos numa pessoa lendo uma história para uma criança, a tradução intralingual obrigaria o adulto a explicar certos trechos ou palavras, enfatizando assim a função metalinguística da mensagem e modificando a percepção da história pela criança. 
A tradução interlingual envolveria a mudança de código, e com isso a mensagem também seria modificada, já que dificilmente existe tradução literal, palavra-porpalavra, entre qualquer par de línguas humanas. ${ }^{2}$ Modificados código e mensagem, as funções poética e metalinguística também seriam re-hierarquizadas, mas as funções conativa e referencial poderiam ou não sofrer. Usando outro exemplo do próprio Jakobson, dizer I hired a worker em inglês não obriga a dizer o sexo desse worker e nem se a ação foi completada, mas essa frase traduzida para o russo obrigaria a presença das duas informações.

Para a TI, as mudanças acontecem em praticamente todos os elementos: o contexto, a mensagem, o código, o canal e o receptor mudam. É inevitável que as funções comunicativas também sejam reorganizadas, mas num nível radical em relação às traduções intra e interlingual. É por isso que as pessoas que leem um livro frequentemente criticam a tradução da obra num filme, dizendo que faltou algo, ou que houve mudanças radicais, ou simplesmente que "o livro é melhor". Tais leitores estavam acostumados com as impressões e emoções transmitidas pelos atos comunicativos do livro, e ao rememorarem as passagens e os trechos transformados agora em filme, não conseguem refazer as associações anteriores. Mas é preciso lembrar que quando tais obras são traduzidas, são feitas justamente para atingirem outros públicos que não estariam prontos para elas, ou provavelmente não estariam interessados em ler. Pensemos no livro O nome da rosa, de Umberto Eco. Para muitas pessoas, é mais interessante, ou conveniente, assistir a um filme de pouco mais de cento e vinte minutos (e com o ator Sean Connery) do que ler um livro de mais de 500 páginas.

Jakobson ainda pensou em como se daria o processamento do pensamento humano ligado à linguagem, apresentando tais ideias em seu outro texto bem conhecido "Two aspects of language and two types of aphasic disturbances" (1955): falar implica a seleção de entidades linguísticas e a combinação delas a outras de maior complexidade. Assim, a pessoa articularia seus pensamentos e sua língua através de metáforas selecionando e substituindo elementos dentro de um catálogo disponível em seu idioleto - e metonímias - combinando e contextualizando tais elementos.

A capacidade de uma pessoa de conseguir realizar certos tipos de tradução está diretamente relacionada à sua perfeita condição cognitiva, sendo que qualquer dos dois distúrbios afásicos pensados por Jakobson afetaria tal capacidade: a perturbação da similaridade afetaria a capacidade da pessoa de pensar através de metáforas e lhe impediria de pensar em sinônimos e traduzir para outras línguas, ou seja, as traduções intra e interlingual seriam seriamente comprometidas, mas a pessoa ainda conseguiria pensar em outros signos (imagens, sons, etc.) relacionados às palavras que the fossem apresentadas. O distúrbio da contiguidade, por outro lado, afetaria a capacidade de pensar por metonímias, o que não atrapalharia em demasia as traduções intra e interlingual. Pensar uma imagem a partir de uma palavra, porém, seria complicado.

As relações entre os tipos de tradução, as funções comunicativas e as afasias apresentadas no presente texto não foram feitas por Jakobson durante sua vida, ou ao menos não foram encontrados textos do autor nesse sentido. O que buscamos aqui foi

\footnotetext{
${ }^{2}$ A expressão "palavra-por-palavra" é usada por Heloísa Barbosa (2004, p. 65), que também diz que "seu uso é restrito, porém, pois é rara uma convergência tão grande entre as línguas", referindo-se ao fato de que a tradução literal dificilmente ocorre quando se traduzem frases ou períodos longos.
} 
pensar, de forma ainda superficial, essas relações, com foco nos tipos de tradução. Da mesma forma, a TI foi pouco explorada e desenvolvida pelo autor russo. A partir de agora voltaremos nossa atenção a ela.

\section{A (falta de) teoria de Jakobson para a tradução intersemiótica}

Apesar de o texto de Jakobson ser um dos mais citados em trabalhos acadêmicos relacionados à TI, ele mesmo pouco desenvolveu o raciocínio sobre esse fenômeno sequer ele apresenta em seu texto de 1959 exemplos do que seria essa tradução ${ }^{3}-$ e, mesmo depois, ele não o retomou em outros trabalhos. Esse aparente descaso de Jakobson faz com que a grande maioria das pessoas que o citam em seus trabalhos façam isso apenas para descartá-lo a seguir, utilizando no lugar outros textos e teorias que refletem mais sobre a TI.

A maioria desses outros textos é bem recente, e isso certamente ocorre devido à necessidade mercadológica das últimas décadas, em que diversos livros e quadrinhos tornaram-se filmes e videogames; quadrinhos e filmes ganharam versões escritas e séries de TV; peças teatrais foram criadas a partir de livros e séries; entre diversas outras possibilidades. A indústria de entretenimentos tem investido pesado nas versões de obras para os mais diversos públicos e isso se reflete na academia, que inclusive conta atualmente com diversos pensadores que já enxergam a TI como algo diverso da tradução, e que seria mais bem chamada de Adaptação. ${ }^{4}$

Entre esses novos trabalhos, podemos citar o de Linda Hutcheon (2006), que analisa as formas como as estruturas e estratégias narrativas são vertidas entre diferentes mídias (como os filmes que se tornam videogames, por exemplo). Por outro caminho, Lauro Amorim (2005) apresenta suas reflexões sobre as traduções e adaptações de duas obras de língua inglesa para o público brasileiro. Também vale lembrar aqui do trabalho de Julio Plaza (2003), que pensou de forma profunda a tradução intersemiótica relacionada à poesia, às artes visuais e à transcriação. ${ }^{5}$ Este autor foi o que mais se debruçou sobre a ideia da transmutação sob a perspectiva do signo peirceano, o que será retomado mais à frente neste trabalho.

Mas as três obras mencionadas acima, assim como quase todos os trabalhos acadêmicos relacionados ao tema, têm em comum o fato de considerarem a tradução ou adaptação de uma obra como um todo, isto é, o que é analisado é como um livro tornouse filme ou vice-versa. Essa ideia parece constante quando se fala de TI ou adaptação. No entanto, não é possível afirmar que fosse exatamente isso que Jakobson quis dizer quando pensou o termo, já que, como dito antes, ele mesmo não apresenta qualquer exemplo de TI em seu texto. Some-se ainda o fato de que o signo peirceano, a base de todo o esquema comunicativo de Jakobson, permite outras reelaborações acerca de suas possibilidades interpretativas. Assim, a proposta deste trabalho é buscar repensar a ideia

\footnotetext{
${ }^{3}$ Existe apenas uma menção à transposição criativa (ele não chama de tradução) da forma poética para a música, a dança, o cinema ou a pintura, mas sem apresentar algum caso ou exemplo.

${ }^{4}$ Além da Adaptação, existem ainda a Transmidialidade e a Intermidialidade, termos também pensados na atualidade para tratar especificamente de adaptações feitas em textos midiáticos para funcionarem em outras plataformas não pensadas originalmente para eles (um filme em quadrinhos, por exemplo). Por ora não discutiremos esses tipos de adaptações e suas relações com a TI de Jakobson.

${ }^{5}$ Julio Plaza foi discípulo do grande poeta brasileiro Humberto de Campos, o qual também explorou de diversas formas a TI na poesia concreta.
} 
de tradução intersemiótica de Jakobson, mostrando que ela pode significar mais do que a simples transmutação de um livro em filme. Com isso esperamos colaborar com os estudos sobre a TI e ampliar as ideias sobre o conceito criado por Jakobson.

\section{A teoria peirceana e a multimodalidade por trás das teorias de Jakobson}

O primeiro passo para cumprir os objetivos propostos foi dado na primeira parte deste trabalho: o desenvolvimento (incipiente) das ideias do ato comunicativo e dos processos cognitivos em relação com a TI. O segundo passo agora é mostrar como a ideia de transmutação pode ocorrer não apenas a nível macro, como o caso do livro em filme, mas também a nível micro, entre palavras e outras unidades menores de texto. ${ }^{6}$ Então revejamos agora as relações entre as ideias de Jakobson e o signo peirceano.

Quando o linguista russo pensou o seu esquema comunicativo, ele não o fez utilizando o signo saussuriano. Como dito antes, o autor russo sempre procurava conhecimentos em outras ciências e ele veio a descobrir a Fenomenologia de Charles Sanders Peirce, um semiólogo norte-americano que desenvolveu efetivamente uma ideia de signo muito mais completa e aplicável a qualquer fenômeno que envolva a transmissão e recepção de sentidos por qualquer ser senciente.

Segundo Peirce (2005, p. 45),

228. Um signo, ou representámen, é aquilo que, sob certo aspecto ou modo, representa algo para alguém. Dirige-se a alguém, isto é, cria, na mente dessa pessoa, um signo equivalente, ou talvez um signo mais desenvolvido. Ao signo assim criado denomino interpretante do primeiro signo. O signo representa alguma coisa, seu objeto. Representa esse objeto não em todos os seus aspectos, mas com referência a um tipo de ideia que eu, por vezes, denominei fundamento do representámen.

Podemos depreender três coisas desta passagem clássica dos textos de Peirce: 1) o signo peirceano é composto de três partes: representamen, objeto e interpretante; 2) o objeto mencionado por Peirce pode ser um objeto do mundo, mas pode ser outro signo interno do pensamento do ser; 3) o signo representa algo para alguém sempre em relação a algum aspecto ou prisma.

Em outra parte de sua extensa obra, Peirce $(1966,5.594)$ fala do pensamento através de signos, e que o objetivo último daquele é a expressão plena de uma ideia, o que aconteceria através de um signo que fosse o desenvolvimento mais completo de outro signo, numa longa cadeia de traduções de signos em outros. O próprio Jakobson cita explicitamente essa passagem de Peirce no seu texto sobre as traduções.

Em outra parte de sua obra, Peirce nos diz que o signo tem potencialidades comunicativas relacionadas ao nível em que opera: num primeiro momento, o signo evoca nada mais do que uma sensação, um instinto no receptor. Este é o nível de primeiridade do signo. Num segundo momento, o signo entra em conflito com outros signos já existentes no pensamento do ser e evoca indícios de outros signos mais desenvolvidos. Esta é a secundidade. No terceiro momento, o signo é então interpretado pelo receptor e incorporado a seus processos cognitivos e mentais. Esta é a terceiridade

\footnotetext{
${ }^{6}$ A ideia de texto que temos aqui é muito mais abrangente, incluindo fenômenos como filmes, séries de $\mathrm{TV}$ e histórias em quadrinhos, conforme o próprio Jakobson admitiu ser possível.
} 
do signo. Imaginemos uma mancha vermelha na parede. Num primeiro momento, ela evocaria num ser humano, vivente numa sociedade ocidental contemporânea, nada mais do que uma sensação (operação de primeiridade), mas que seria rapidamente sobrepujado pela tentativa de compreender aquela mancha naquele local (secundidade): poderia ser uma mancha de tinta derramada por um pintor desleixado, ou a indicação de que alguém foi ferido ali. Finalmente, já contextualizada a localização da mancha no tempo e no espaço, ela evocaria sentidos relacionados a tal contexto (terceiridade): a mancha poderia estar dentro de um museu, o que poderia indicar que se trataria de uma obra de arte.

Há alguns autores que desenvolveram a TI através da teoria semiótica de Peirce. Júlio Plaza (2003), já mencionado, é um deles. Mas também encontramos os trabalhos de Júlio Jeha (1996) e de Daniella Aguiar e João Queiroz (2009).

Jeha $\left(1996\right.$, p. 84, tradução nossa ${ }^{7}$ ) considera que a experiência deve ser levada em conta na TI: "um indivíduo experimenta um signo (um texto) que representa, ou se refere a, um fenômeno do mundo e isso cria algum sentido (o interpretante) em sua mente.”. Mas a representação advinda dessa experiência, o signo criado, é que dá início à longa sequência de outros signos que poderão culminar num texto, numa paráfrase ou num filme. Para esse encadeamento acontecer é preciso lembrar que a TI ocorre em outras dimensões que não a linguística. Isso faz todo o sentido quando consideramos que o pensamento é feito de signos, conforme Peirce mesmo apontou. É graças à capacidade de abstrair um signo, através da percepção de certos aspectos dele, e através da associação com outros signos, que alguém pode imaginar uma cena de filme ao ler certa passagem de um livro.

Aguiar e Queiroz $\left(2009\right.$, p. 205, tradução nossa $\left.{ }^{8}\right)$ trazem a ideia de tradução como um processo em camadas: "TI pode ser descrita como um processo multihierárquico de relações entre camadas de representações semi-independentes. As camadas estruturadas não atuam independentemente, mas são autônomas em termos funcional e descritivo.". Retomando a ideia de que o signo representa algo para alguém sempre sob certo prisma, podemos inferir que um único signo pode traduzir-se em diversos outros, dependendo do modo, das relações sígnicas, que se utilize para interpretá-lo. Mas não necessariamente a hierarquia de sentidos num texto fonte será reproduzida num texto alvo: "Se a tradução de uma obra literária para uma coreografia de dança resulta em materiais e estruturas totalmente diferentes, como é possível comparar 'a fonte e o alvo semióticos'?” (Ibidem, p. 205, tradução nossa ${ }^{9}$ ).

A ideia de camadas de sentidos num texto, que pode ou não ser um único signo, pode ser compreendida de outra forma: a multimodalidade. Já existe até mesmo um novo campo de estudos, os Estudos Multimodais (Multimodal Studies), para pensar a comunicação humana através dos diversos modos ou sistemas semióticos possíveis. A noção de multimodalidade nasceu como contraparte ao crescimento dos estudos de Linguística sistêmico-funcional. Estes últimos buscavam demonstrar como os textos

\footnotetext{
7 "an individual experience a sign (a text) that stands for, or refers to, a phenomenon in the world and that creates some sense (the interpretant) in his mind.".

8 "IT can be described as a multi-hierarchical process of relation between semi-independent layers of descriptions. The layers of organization do not act independently but they are autonomous in functional and descriptive terms.".

9 "If a translation from a literary work into a dance choreography results in very different materials and structures, how is it possible to compare 'semiotics source and target'?".
} 
expressavam seus significados dentro dos contextos e utilizando todas as potencialidades da língua. Tais estudos, porém, debruçavam-se quase sempre sobre a língua falada e escrita, deixando de lado outras possibilidades comunicativas dentro de uma sociedade, como os gestos, as cores, etc. Percebendo isso, outros pensadores passaram a considerar as possibilidades comunicativas dos elementos não verbais. Então, cada um dos elementos comunicativos de um texto equivale a um modo, e a interação entre os diversos modos é a multimodalidade. Um dos ícones dessa vertente investigativa é Gunther Kress (2009). Para o autor, o modo é resumido como "um recurso socialmente formado e culturalmente aceito para fazer algum sentido" (Ibidem, p. 54, tradução nossa ${ }^{10}$ ). Mais do que isso, porém, pensar a multimodalidade obriga a pensar em todas as formas possíveis pelas quais uma pessoa, um texto ou qualquer coisa pode transmitir algum sentido. Gestos, cores e até mesmo cheiros podem ser modos, cada um evocando no receptor/leitor um certo conhecimento de mundo adquirido socialmente para que possa conseguir captar o que aquele modo quer dizer. ${ }^{11}$

Já que é possível imaginar uma cena, apenas uma, de um filme através da leitura de um trecho, e apenas um, de um livro, então podemos acreditar que a TI deve ocorrer a níveis menores, entre enunciados, discursos e unidades lexicais dentro de um filme ou texto. E tais unidades não necessariamente precisam se corresponder num sentido restrito. Uma forma de perceber, de sentir, uma palavra pode ser traduzida em outro modo possível, mas relacionado àquela palavra, como uma cor, uma imagem ou mesmo um cheiro. Além disso, mais de um tipo de tradução pode ocorrer ao mesmo tempo, já que um texto pode ser multimodal e seus signos podem ser interpretados de mais de uma forma simultaneamente. Vamos explorar tal possibilidade agora.

\section{As histórias em quadrinhos e suas (micro) possibilidades tradutórias}

Existe um tipo de texto em que diversos modos de transmissão de sentidos se manifestam e se entrelaçam o tempo todo, e é somente graças a esse entrelaçamento que tal texto torna-se tão interessante: a história em quadrinhos (HQ), ou apenas quadrinhos. Podemos encontrar numa única vinheta de uma HQ palavras, imagens de objetos, imagens humanas e certos sinais que podemos chamar de elementos quadrinísticos (EQ) atuando ao mesmo tempo para transmitir uma narrativa ao leitor. Um exemplo clássico de HQ ocidental são os álbuns do personagem francês Asterix, dos quadrinistas René Goscinny e Albert Uderzo. Cada álbum dos "intrépidos gauleses" é recheado de denso conteúdo linguístico e sociocultural, havendo referências constantes a lugares, pessoas e situações tanto da Europa das décadas de 1960 e 1970, época de criação da grande maioria dos álbuns, quanto de outras épocas e momentos da História Mundial, todos transportados para o tempo em que ocorreriam as aventuras dos gauleses, o ano 50 a.C. A grande intertextualidade de Asterix é certamente um desafio considerável para qualquer tradutor que resolva verter a obra para outra língua. ${ }^{12}$

\footnotetext{
10 "a socially shaped and culturally given resource for making meaning".

${ }^{11}$ Um trabalho mais completo que aborda a questão da multimodalidade e como ela pode ser usada na análise de traduções intersemióticas é o texto de Adriano da Silva (2014).

12 Por intertextualidade, remetemos ao trabalho de Kristeva (1974), para quem o texto é como uma malha, costurada por e em outros textos, entendendo-se texto por livros, filmes, discursos orais, teorias científicas e/ou sociais etc. Desse modo, um texto sempre remete a outro, que remete a outro, indefinidamente.
} 
Vamos mostrar agora dois casos, de dois álbuns distintos, em que houve TIs micro-textuais. As análises foram feitas através da comparação de vinhetas no original em francês com a tradução para o português brasileiro, o que indica que a metodologia utilizada foi qualitativa documental. Consideramos como modos possíveis de transmissão de sentidos, neste caso, os mencionados no parágrafo anterior: as palavras toda forma de manifestação verbal que apareça na vinheta; os EQs - os sinais pertencentes ao universo dos quadrinhos e que o caracterizam, como os balões, as linhas de movimento, as onomatopeias, etc.; as imagens de objetos - todas as imagens que remetem a objetos da realidade; as imagens humanas - todas as imagens que remetem a corpos humanos e suas possibilidades comunicativas (gestos, linguagem corporal e expressões faciais).

Devemos considerar ainda que, no Brasil, tradicionalmente as imagens dos quadrinhos (ou o que se considera imagem) não são traduzidas. Há leis de direitos autorais específicas para palavras e imagens, e modificar a imagem custa mais caro às editoras, já que, além da questão do direito autoral, exige a contratação de um artista gráfico. Por outro lado, muitos leitores compram os quadrinhos justamente pelas imagens, que são consideradas então obras de artes. ${ }^{13}$

O primeiro par de vinhetas analisadas (Figuras 2 e 3) vem do álbum Asterix et le chaudron (2010) e sua tradução Asterix e o caldeirão (1986). Vemos o personagem Obelix, companheiro inseparável de Asterix, correndo e gesticulando, aparentando nervosismo e reclamando que os habitantes da aldeia gaulesa deixaram Asterix ir sozinho para uma missão.

Figuras 2 e 3: Uma imagem traduzida em palavra
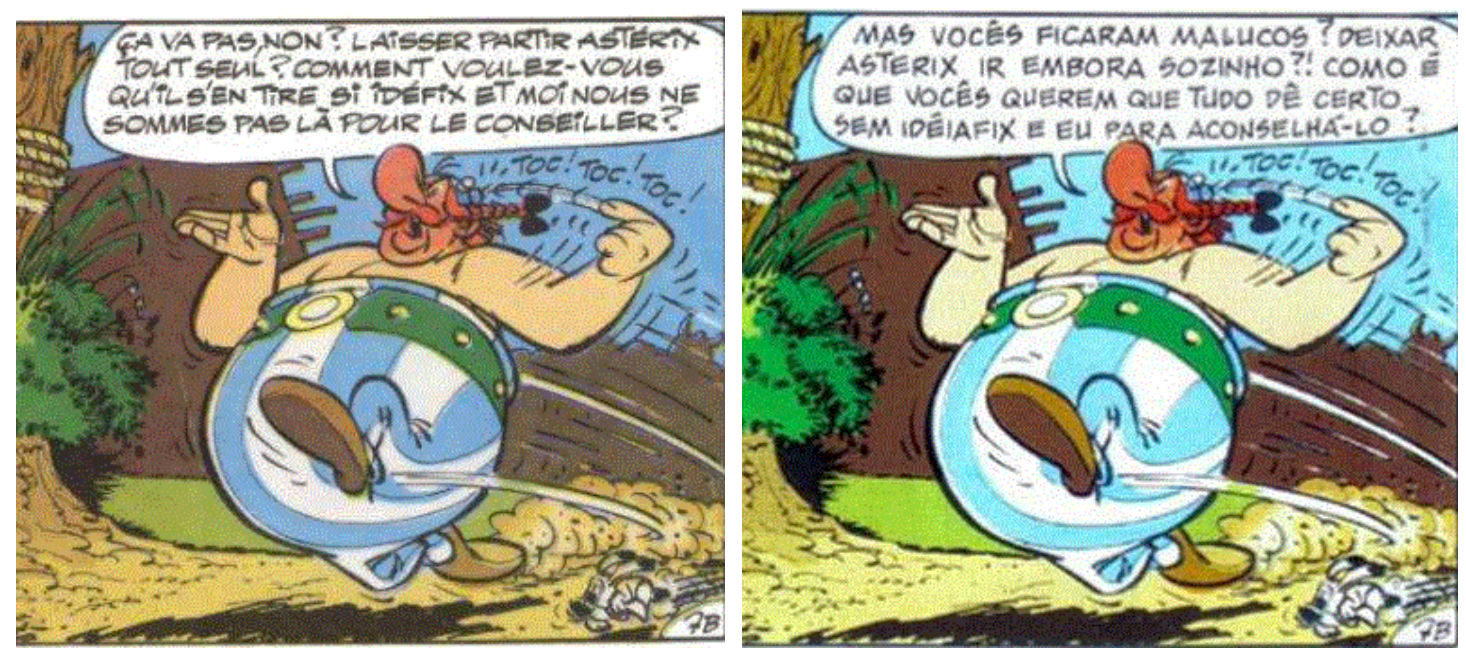

Fonte: Goscinny e Uderzo (2010 e 1986)

Em termos de modos, ou sistemas semióticos, temos: modo palavras: o acréscimo da frase "Mas vocês ficaram malucos?" no texto traduzido, a qual não tem um correspondente no balão original francês; modo EQ: a onomatopeia Toc! Toc! Toc!; e modo imagem humana: o gesto de bater na cabeça com o dedo indicador.

\footnotetext{
13 Atualmente já existem casos de traduções de quadrinhos em que a imagem é modificada também, mas dado o nosso objeto de estudo, não nos aprofundaremos mais no assunto.
} 
O que chama a atenção aqui é a palavra malucos. A menção à loucura aparece, porém, apenas na tradução. Não há qualquer palavra equivalente no original em francês. Por outro lado, o gesto de Obelix é facilmente reconhecível por qualquer cidadão francês, mas não por um cidadão brasileiro mediano: significa chamar alguém de maluco. Assim, um gesto foi traduzido numa palavra. Um modo, um sistema semiótico foi transmutado em outro. Falando dos três tipos de tradução de Jakobson, temos a tradução interlingual ocorrendo entre os conteúdos de cada balão (as palavras e expressões foram traduzidas do francês para o português), mas também temos uma tradução intersemiótica ocorrendo entre o gesto "humano" de Obelix e a palavra malucos, e ambas ao mesmo tempo. O tradutor certamente teve de lidar com a imutabilidade da imagem e teve sua tradução restrita ao espaço dentro do balão, mas ainda assim conseguiu ajudar o leitor a entender o sentido daquele gesto típico da cultura francesa. $\mathrm{O}$ motivo que levou o tradutor a fazer essa escolha não vem ao caso agora.

O segundo par de vinhetas (Figuras 4 e 5) vem do álbum Asterix chez les bretons (2008) e sua tradução Asterix entre os bretões (1985). Vemos os personagens bretões Jolitorax e Relax muito irritados por algo que os romanos acabaram de fazer a eles, e mostrando essa raiva ao seu modo bretão, com Asterix observando atônito aquele tipo de manifestação.

Figuras 4 e 5: Tradução de estereótipo

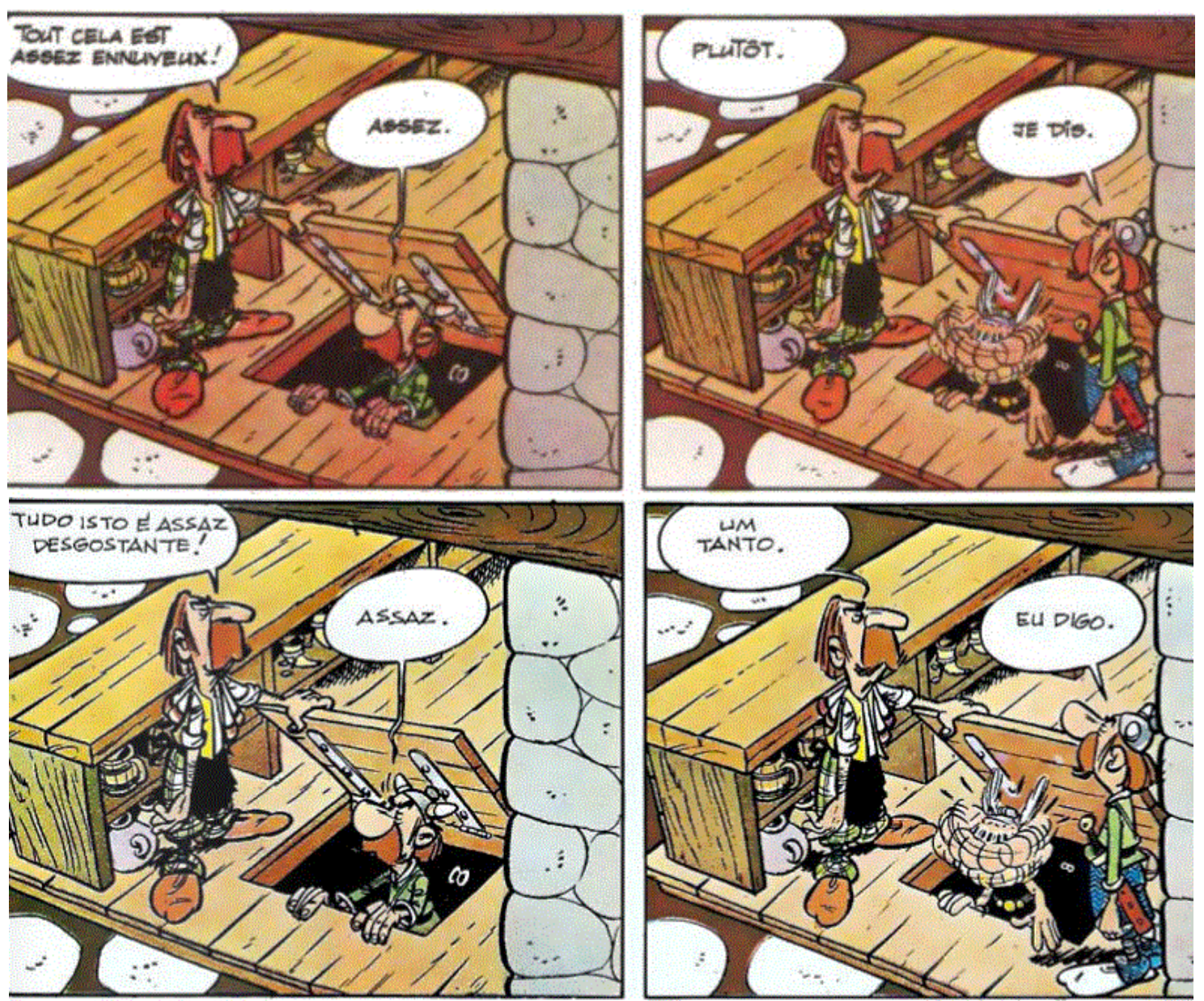

Fonte: Goscinny e Uderzo (2008 e 1985) 
Olhando para os modos, temos: modo palavras: traduções quase literais entre texto fonte e texto alvo; modo EQ: três balões com perceptíveis espaços em branco dentro deles; e modo imagem humana: a caracterização dos bretões (postura ereta, feições graves).

Para compreender como a tradução acontece neste caso, é preciso evocar outro conceito: o estereótipo. Todos os povos contatados por Asterix e Obelix em suas aventuras correspondiam a estereótipos de povos da atualidade francesa de 1960 e 1970, conforme nos explica Maria Vila Barbosa (2014). No caso do álbum analisado, o estereótipo dos britânicos, representados pelos bretões, era o enxergado pelos franceses na época, que por sua vez era embasado em literaturas, como as obras de Pelham Grenville Wodehouse ${ }^{14}$, e alguns programas de TV ingleses, como a série Monty Python.

Feita a observação acima, sigamos com a análise. O estereótipo britânico é muito bem apresentado pelos criadores de Asterix através de três modos: nas imagens humanas, mostrando personagens eretos e austeros; nas palavras, com frases curtas e contundentes; nos EQs, com balões realçando as poucas palavras e reforçando a característica fleumática delas. Ao nível de tradução interlingual, o tradutor manteve as poucas palavras e a contundência delas. Mas se consideramos o estereótipo como um sistema semiótico, um signo que representa um povo, houve também uma tradução intralingual, já que a ideia francesa do que seja um britânico é muito bem transmitida para o público brasileiro, tanto pelas imagens humanas como pelas EQs. Ou seja, a partir de agora o estereótipo pelo qual os franceses enxergam os britânicos é conhecido e absorvido pelos brasileiros, sem que para isso houvesse qualquer explicação em forma de palavras. Novamente, uma tradução intralingual e uma interlingual ocorreram simultaneamente.

Há diversos outros pares de quadrinhos em Asterix que nos permitem perceber mais de um tipo de tradução ocorrendo ao mesmo tempo, mas acreditamos que os dois acima já sejam suficientes para comprovar a ideia ora defendida.

\section{Alguma discussão}

Não sabemos o real motivo porque Roman Jakobson não se debruçou mais sobre a TI. Devemos admitir: ele foi um dos maiores autores da Linguística e, como dito no começo deste trabalho, pensou em diversos outros aspectos das línguas e linguagens humanas transmitidas através da fala e da escrita. Talvez por isso mesmo dedicou pouco tempo, e interesse, para pensar a comunicação por gestos, imagens e outras formas semióticas. Também devemos lembrar que Jakobson desenvolveu a maior parte de sua obra entre as décadas de 1920 e 1960 e que nessa época, tanto na Rússia como nos Estados Unidos (países onde viveu e trabalhou), o uso de imagens para a comunicação humana ainda era muito limitado.

Apesar de entendermos que é possível pensar a TI sem necessariamente evocar a obra de Jakobson, utilizando apenas a semiótica peirceana, acreditamos que esta teoria seja ampla demais e mais focada na percepção dos seres (ou pessoas) sobre as

\footnotetext{
${ }^{14}$ São famosos os personagens Bertie e Jeeves do escritor inglês, que representam através de paródias toda a idiossincrasia dos britânicos. Para mais informações sobre os personagens e sobre o universo de Wodehouse, ler os livros Thank you, Jeeves e Jeeves in the offing, do autor (Arrow Books).
} 
experiências e sentidos que lhes vêm sob a forma de signos. A obra de Jakobson, por outro lado, está muito mais interessada nas relações linguísticas, socioculturais e cognitivas advindas dessas percepções, e foram pensadas especificamente para as relações entre pessoas e povos.

Revendo agora a classificação de Jakobson, podemos pensar que a tradução intralingual poderia na verdade ser chamada de tradução intrassemiótica, já que é possível pensar, por exemplo, na tradução de objetos com certa utilidade ou representação numa cultura por objetos com a mesma utilidade ou representação em outra cultura. ${ }^{15}$ Por outro lado, essa tradução intrassemiótica poderia ser um quarto tipo, mantendo-se a tradução intralingual, junto com a interlingual, dentro da esfera verbal. De qualquer modo, acreditamos que a classificação de Jakobson ganhou uma nova interpretação, que é efetivamente aplicável e concorrente com outras teorias e outros pensadores das traduções, incluída aí a intersemiótica.

\section{REFERÊNCIAS}

AGUIAR, D.; QUEIROZ, J. Towards a Model of Intersemiotic Translation. The International Journal of the Arts in Society. v. 4, n. 4, p. 203-210, 2009.

AMORIM, L. M. Tradução e Adaptação: Encruzilhadas da Textualidade em Alice no País das Maravilhas de Lewis Carrol, e Kim, de Rudyard Kipling. São Paulo: Editora UNESP, 2005.

BARBOSA, H. G. Procedimentos técnicos da tradução: uma nova proposta. 2. ed. Campinas: Pontes, 2004.

GOSCINNY, R.; UDERZO, A. Asterix entre os bretões. Tradução de Jorge Faure Pontual. Rio de Janeiro: Record. 1985.

Asterix e o caldeirão. Tradução de Cláudio Varga. Rio de Janeiro: Record. 1986. . Astérix chez les Bretons. Édition 07. Paris: Hachette. 2008 [1966]. Astérix et le chaudron. Édition 07. Paris: Hachette. 2010 [1969].

HOLENSTEIN, E. Jakobson: o Estruturalismo Fenomenológico. Lisboa: Editorial Veja, 1975.

HUTCHEON, L. A theory of adaptation. New York: Routledge, 2006.

KRESS, G. What is mode? In: JEWET, C. (Ed.). The Routledge Handbook of Multimodal Analysis. London: Routledge. 2009. p. 54-66.

JAKOBSON, R. Linguistics and Poetics. In: SEBEOK, T. A. Style in Language. Cambridge: MIT Press, 1960.

\footnotetext{
${ }^{15}$ Isso efetivamente já ocorreu na tradução do desenho animado (anime) japonês Doraemon para a cultura norte-americana: há uma cena em que os hashis segurados pelos personagens durante uma refeição são substituídos por garfos na versão traduzida. Outra cena substitui as notas de dinheiro japonesas por dólares. Muitas outras domesticações ocorrem, a fim de deixar o anime mais "palatável" para o novo público. Mais detalhes em: <http://www.deculture.es/2014/05/13/doraemon-absurda-censuraoccidentalizacion-estados-unidos/>. Acesso em: 09 jul. 2017.
} 
Aspectos linguísticos da tradução. In: Linguística e Comunicação. Tradução de Izidoro Blikstein e José Paulo Paes. São Paulo: Cultrix, 2003

JAKOBSON, R.; HALLE, M. Two Aspects of Language and Two Types of Aphasic Disturbances. In: Fundamentals of Language. The Hague/Paris: Mouton, 1956.

JEHA, J. C. Intersemiotic translation: the Peircean basis. Anais da Semana de Estudos Germânicos, 11. Belo Horizonte: UFMG, 1996. p. 81-87.

KRISTEVA, J. Introdução à semanálise. Tradução de Lúcia H. F. Ferraz. São Paulo: Perspectiva, 1974

PEIRCE, C. S. Collected Papers of Charles Sanders Peirce, ed. by Charles Hartshorne, Paul Weiss \& Arthur W. Burks. Cambridge: Belknap Press, 1931-1966. 8 v.

Coleção Estudos.

Semiótica. Tradução de José T. C. Neto. São Paulo: Perspectiva, 2005.

PLAZA, J. Tradução Intersemiótica. São Paulo: Perspectiva. 2003.

SILVA, A. C. Metodologia de análise em traduções de histórias em quadrinhos: uma possibilidade para geração de dados. In-Traduções, Florianópolis: UFSC, v. 6, n. 10, p. 124-141, 2014.

VILA BARBOSA, M. M. Delirant isti translators! Análise dalgúns elementos de difícil traduzadaptación en Astérix. Herméneus. n. 16. Soria: Universidad de Valladolid, 2014. p. 291-327. Disponível em: <http://uvadoc.uva.es/handle/10324/8632>. Acesso em: 09 jul. 2017.

Recebido em: 30/08/2017

Aprovado em: 06/07/2018 